\title{
Sylwester Szafarz, Cywilizacja XXII wieku, Warszawa 2015, pp. 220
}

I $s$ the $22^{\text {nd }}$ century going to be the century of China? How in the new world order will the United States find their place? Where in this political puzzle will be a place for the Russian Federation and Europe? Will the European Union fall apart or perhaps undergo transformation?

These and other questions about the world's future in the next century Sylwester Szafarz attempts to answer in his book entitled Cywilizacja XXII wieku (Civilization of the $22^{\text {nd }}$ Century). The publication was released in 2015 by the Polish publishing house "Kto jest Kim".

The author is a graduate from Faculty of International Trade at the Warsaw School of Economics and the Faculty of Journalism at the Warsaw University. He also underwent internships and post-graduate traineeship in France, UK, and USA. For many years he was involved in diplomatic service and worked as a member of the Civil Service and the Foreign Service. Furthermore, he was working on diplomatic and consular posts in Paris, Beijing, and Shanghai, to list a few. In his career he advised the Polish Prime Ministers. More- over, he worked in the Polish President's Office. His professional work was also associated with economy - the author had the opportunity to gain experience, e. g. as CEO of Polish Defense Company and as an expert at the Head Office of Pekao SA Bank. Apart from diplomatic and economic activities, the author worked as a journalist and international columnist. He was the chief editor of the monthly Trade Union newspaper, issued in the Czech Republic during the Velvet Revolution. What is more, he is responsible for several studies on the development of the global state of affairs. Such a wide range of professional interests, as well as extensive knowledge in these areas, certainly contributed to the creation of publication in the form, which was presented to the readers.

S. Szafarz's publication consists of three main parts apart from the introduction and conclusion. The first chapter is called: Coraz blizej do XXII wieku (Getting Closer to $22^{\text {nd }}$ Century). The author focuses attention on general considerations about the situation in the world in the next century. Further two parts include presentation of regional 
issues entitled as follows: Powstanie $i$ rozwój BRICS ${ }^{1}$ oraz Problematyka chinska (The Emergence and Development of BRICS and The China Issues). In the author's deliberations emerges the thesis that the $22^{\text {nd }}$ century will be the era of China's superpower. It is hard for the reader to disagree with this statement. At the same time, however, the reader should be aware that neither the United States nor Europe will disappear from a world map till that time. Therefore, it seems completely incomprehensible to omit their role in the presented prognosis. It is obvious that after stating that China will gain power status, this argument will be predominant in the monograph; however, the proportion with regards to other arguments is completely unjustified. The description of People's Republic of China is shown on approx. 100 pages (that is, almost half of the entire book). On the other hand, the development of BRICS is presented on approx. 40 pages and Europe and the US are mentioned in a few dozen of sentences. The title can undoubtedly be interpreted as a reflection on Chinese civilization, which will be - according to S. Szafarz's opinion - the main civilization of the $22^{\text {nd }}$ century. However, it seems that in spite of all, the world's civilization will not be limited to one culture and one region.

The unquestionable advantage of the reviewed monograph is the writer's competence and open approach to the subject. Considerations contained on the pages are supported by data and facts, and world's civilization depicted with the utmost accuracy. The publication contains interesting and bold analysis and evaluation of

${ }^{1}$ BRICS is the acronym for an association of five major emerging national economies: Brazil, Russia, India, China, and South Africa. the immediate forecasted trends in global politics that are associated with displacement of the "civilization pole" towards the Asia-Pacific region.

The writer with a great audacity presents a "global macro bailout" (Szafarz, 2015), in which - as he notes - presents the issues of which the implementation could save modern civilization. Thus for example: S. Szafarz mentions about the need to form a global agreement with all countries and peoples who would support the declaration to "break with the dreadful past" (Szafarz, 2015), the need to recognize all humanity as one nation - the Earthlings or the creation of a single state - the Republic of the Earth. Undoubtedly, the author's plans and ideas cannot deny his creativity and courage, but it seems that they should be treated more as a utopian and wishful thinking than as a possibility that has a realistic chance of implementation.

However, it is worth mentioning that this monograph is a study pointing to the latest trends in the international sphere. In addition, the huge advantage of the Cywilizacja XXII wieku (Civilization of the $22^{\text {nd }}$ Century) is the author's thorough analysis in relation to the Pacific region. Sylwester Szafarz indicates the factors that need to be used in the construction of a new civilization and originate from demographic potential, natural and intellectual resources of the region. In the conclusion he proposes a thesis that goodwill and determination are needed to successfully carry out the plan of creating a new civilization.

In the monograph are also statements presenting that the modern world is still dominated by competition, violence and the desire to defeat an opponent. Undoubtedly, the reader can agree with the author's thoughts but should remember 
that countries strive to have the strongest position in the international arena and this can be achieved in fact by competition and hostile actions towards adversaries.

The monograph written by Sylwester Szafarz is a good read. This is certainly the result of the author's good writing skills. The reader clearly sees the author's creativity and courage to present his forecasts. The only drawback, which from the editorial point of view can make it difficult to read and cause the impression of text underdevelopment, is the fact that the author, quoting the work of other researchers for the first time, gives their full name, however in further quotations only provides their initials. In my opinion, such a writing technique gives the impression of reading private notes and not a serious monograph.

In conclusion, it should be emphasized that this publication is certainly worth readers' attention. This is a good piece of literature for all those who are interested in the world's forecasts and at the same time are not afraid to go with their proposals beyond the next 30 years. The arguments are very audacious, sometimes controversial, and the reader cannot deny author's diligence and honesty, which definitely positively influences the overall perception of Cywilizacja XXII wieku. 